\title{
Surface Modification of Steel by Nickel Coating in Electrochemical Process
}

\author{
S. Gunaselvi ${ }^{1, *}$, P. Satheeshkumar ${ }^{2}$ and M. Jeganathan ${ }^{3}$ \\ ${ }^{1}$ Post Doctoral Fellowship in Civil Engineering, Lincoln University College, Malaysia. \& Assistant Professor, Department of \\ Civil Engineering, Valliammai Engineering College, Chennai, SRM University, Tamilnadu 603203, India \\ ${ }^{2}$ Post Doctoral Fellowship in Architecture, Lincoln University College, Malaysia \\ ${ }^{3}$ Post Doctoral Fellowship in Environmental Science, Lincoln University College, Malaysia
}

Corresponding Author Email: skgunaselvi@yahoo.co.in

\begin{abstract}
Due to the rebar corrosion problems, quite the value of construction is being spent towards repair and renovation of the concrete structures. If rebar corrosion problem continues, lifeline structures are subjected to sudden collapse. So as to avoid the catastrophic failures, effective additional protective measures must be undertaken within the construction stage itself. The target of this investigation is to switch the surface of the low-carbon steel rebar by electroplating in three different coating thicknesses. The efficiency of corrosion resistance properties are evaluated by various electrochemical corrosion tests. This study starts from Brenner and Riddel who developed their work by electroless deposition of nickel. the aim of this study was to calculate the corrosion rate by gravimetric weight loss method supported the electrochemical corrosion test. Also to reinforce the performance of corrosion resistance with three different coating thicknesses like $10 \mu, 20 \mu$, and $30 \mu$ supported the time consumption in low-carbon steel rebar with and without 3.5\% Nacl. Potential time studies confirmed the steadiness of coating even within the presence of aggressive chloride medium during one month exposure. $12 \mathrm{~V}$ accelerated impressed voltage test results indicate that the time taken for initial crack was doubled for $20 \mu$ coated steel.
\end{abstract}

Keywords: electroless deposition, nickel coating, corrosion resistance, potential time studies, impressed voltage test Received: December-16-2019, Accepted: February-28-2020, https://doi.org/10.14447/jnmes.v23i2.a08

\section{INTRODUCTION}

Electroless (autocatalytic) plating involves the presence of a chemical reducer in solution to scale back metallic ions to the metal state. the invention of electroless coatings is credited to Abner and Riddell [1] within the year 1940s. Today electroless nickel has grown up into a really substantial segment of the metal products finishing industry. Engineering applications for electroless nickel are often found in virtually every industry. Various physical characteristics of electroless nickel coatings, like hardness, wear resistance, coating uniformity and corrosion resistance, also because the ability to plate non-conductive surfaces make this a coating of choice for several engineering applications. The corrosion of reinforcing steel is usually determining by the effect of chemical admixtures, on the corrosion of embedded steel reinforcement in concrete, exposed to chloride environments like electrochemical corrosion methods of potential time studies and by means of the impressed current technique etc. this is often done to induce a big degree of corrosion of reinforcing bars embedded in concrete in limited available time. The protection behaviour of steel reinforcement embedded in concrete with different coatings has been frequently wont to study the corrosion performance of steel embedded in chloride contaminated concrete, effect of reinforcement corrosion on the cracking of concrete cover, bond behaviour, and load-bearing capacity of ferroconcrete structural members, potential time measurements, and impressed current technique as shown in Table 1.

The need for protective coating to low-carbon steel reinforcement bar is to develop necessary bond strength at the rebar concrete interface for the reliable performance of the ferroconcrete structures. Bond behaviour of the galvanized inhibited cement slurry coated and fusion bonded epoxy coated bars with different coating thickness is assessed and compared. It had been observed that the coated steel rebars improves the bond strength to plain low-carbon steel bars. The galvanizing and epoxy coating reduce the bond strength at higher thickness of coatings. On the opposite hand inhibited cement slurry coated rebars bond strength improves further at the upper thickness of coating. Epoxy shows that the coating thickness and therefore the damage present within the coatings will influence the adhesion loss between the steel surface and coatings and blister formation. Fusion bonded epoxy coating is one among the effective methods of coating rebars. The fusion bonded coating may be a specialized job carried during a factory and not at the location work. Although epoxy coated rebars have a superb protection to corrosion in an aggressive environment, there are a couple of limitations. The coating may get damaged during the vibration of concrete. The treatment is extremely costly nearly as costly as that of steel. All the above, this method of protection to the steel is being given to a flyover and other structures at Mumbai. The objective of the coating to steel rebar is to supply a durable barrier to aggressive materials. The coatings should be robust to face up to the fabrication of reinforcement cage, and therefore the pouring of concrete and compaction by vibrating needle. Central electro chemical research institute (CECRI) karaikudi has suggested various methods for prevention of corrosion in steel reinforcement in concrete. The steps involved during this process are

$\begin{array}{ll}\text { i. } & \text { Defrosting } \\ \text { ii. } & \text { Phosphate }\end{array}$


Table 1. Review of literature studies

\begin{tabular}{|c|c|c|c|c|}
\hline S.No & Authors & Title & Types of study & Remarks \\
\hline$[1]$ & $\begin{array}{c}\text { Abner and } \\
\text { Rieddel [1950] }\end{array}$ & $\begin{array}{l}\text { Nickel plating by chemical } \\
\text { reduction }\end{array}$ & Electroplating chemical reaction & $\begin{array}{c}\text { Developed formulations and practices for Ni-P } \\
\text { deposition on carbon steel without the aid of an } \\
\text { electric current. }\end{array}$ \\
\hline$[2]$ & $\begin{array}{l}\text { Rengasamy et } \\
\text { al. [1988] }\end{array}$ & $\begin{array}{l}\text { Inhibited and sealed } \\
\text { cement slurry coating of } \\
\text { steel rebar }\end{array}$ & $\begin{array}{l}\text { Performance evaluation test, } \\
\text { alternate wetting and drying test } \\
\text { and performance in the presence } \\
\text { of chloride admixture were also } \\
\text { discussedelaborately }\end{array}$ & $\begin{array}{l}\text { Applied to steel rebars for its corrosion } \\
\text { protection lead to economy and efficiency } \\
\text { higher than other coating systems. }\end{array}$ \\
\hline$[3]$ & $\begin{array}{c}\text { Singh and } \\
\text { Ghosh [2006] }\end{array}$ & $\begin{array}{l}\text { Electroless nickel- } \\
\text { phosphorus coatings to } \\
\text { protect steel reinforcement } \\
\text { bars from chloride induced } \\
\text { corrosion }\end{array}$ & $\begin{array}{l}\text { EIS and DC polarization } \\
\text { techniques, SEM and XRD } \\
\text { studies have been used to study } \\
\text { the kinetics and mechanism of } \\
\text { corrosion protection and to } \\
\text { characterize corrosion products. }\end{array}$ & $\begin{array}{l}\text { Medium phosphorus content is more } \\
\text { impervious and protective in comparison to } \\
\text { high phosphorus coating }(16 \%) \text {. XRD studies } \\
\text { show that the medium phosphorus electroless } \\
\text { nickel (MEPEN) is microcrystalline in nature } \\
\text { and forms } \mathrm{Ni}_{2} \mathrm{O}_{3} \text { and } \mathrm{Ni}_{5} \mathrm{P}_{2} \text { passive films on its } \\
\text { surface. }\end{array}$ \\
\hline [4] & Pyc et al [1998] & $\begin{array}{l}\text { Corrosion Protection } \\
\text { Performance of Corrosion } \\
\text { Inhibitors and Epoxy- } \\
\text { Coated Reinforcing Steel } \\
\text { in a Simulated Concrete } \\
\text { Pore Water Solution }\end{array}$ & Adhesion tests and hardness. & $\begin{array}{l}\text { Coating thickness and damage present in the } \\
\text { coating would influence the adhesion loss } \\
\text { between the coatings and steel surface and } \\
\text { blister formation. }\end{array}$ \\
\hline$[5]$ & $\begin{array}{l}\text { Sidney } \\
\text { Freedman } \\
\text { [1998] }\end{array}$ & $\begin{array}{l}\text { Corrosion Resistance of } \\
\text { Reinforcement in } \\
\text { Architectural precast } \\
\text { concrete }\end{array}$ & $\begin{array}{l}\text { Chloride ingress and } \\
\text { carbonation. Criteria for } \\
\text { evaluating crack widths, } \\
\text { Methods of protecting } \\
\text { reinforcement. }\end{array}$ & $\begin{array}{l}\text { High quality concrete with strength between } \\
34.50 \text { and } 41.4 \mathrm{Mpa} \text { and water cement ratio of } \\
0.4 \text { or less is adequate in preventing corrosion. }\end{array}$ \\
\hline$[6]$ & $\begin{array}{c}\text { Ahmad } \\
\text { Shamsad [2009] }\end{array}$ & $\begin{array}{l}\text { Techniques for inducing } \\
\text { accelerated corrosion of } \\
\text { steel in concrete }\end{array}$ & $\begin{array}{l}\text { The effectiveness of } \\
\text { electrochemical techniques } \\
\text { applied for the prevention of } \\
\text { reinforcement corrosion }\end{array}$ & $\begin{array}{l}\text { The impressed current technique commonly } \\
\text { used for accelerating reinforcement corrosion } \\
\text { in small- as well as large-sized concrete } \\
\text { specimens in the light of state-of-the-art } \\
\text { information. }\end{array}$ \\
\hline [7] & $\begin{array}{l}\text { El Maaddawy, } \\
\text { and Soudki, } \\
\text { [2003] }\end{array}$ & $\begin{array}{l}\text { Effectiveness of Impressed } \\
\text { Current Technique to } \\
\text { simulate corrosion of steel } \\
\text { in concrete }\end{array}$ & $\begin{array}{l}\text { The influencing of varying the } \\
\text { impressed current density level } \\
\text { between } 100 \text { and } 500 \mu \mathrm{A} / \mathrm{cm}^{2} \text {. }\end{array}$ & $\begin{array}{l}\text { The result showed that, accelerated corrosion } \\
\text { using the impressed current technique was } \\
\text { effective in inducing corrosion of the steel } \\
\text { reinforcement in concrete with respect to } \\
\text { Faraday's law. }\end{array}$ \\
\hline$[8]$ & $\begin{array}{l}\text { Thangavel et al } \\
\text { [1995] }\end{array}$ & $\begin{array}{l}\text { Influence of Protective } \\
\text { coatings on steel- concrete } \\
\text { bond }\end{array}$ & $\begin{array}{l}\text { Bond behavior of the galvanized } \\
\text { inhibited cement slurry and } \\
\text { fusion bonded epoxy coated bars } \\
\text { with two different coating } \\
\text { thickness is assessed and } \\
\text { compared }\end{array}$ & $\begin{array}{l}\text { The galvanizing and epoxy coating reduce the } \\
\text { bond strength at higher thickness of coatings. } \\
\text { On the other hand for inhibited cement slurry } \\
\text { coated rebars, bond strength improves at higher } \\
\text { thickness of coatings }\end{array}$ \\
\hline [9] & Haji [2008] & $\begin{array}{l}\text { Performance evaluation of } \\
\text { protective coating on steel } \\
\text { rebars }\end{array}$ & $\begin{array}{l}\text { Chemical resistance test, applied } \\
\text { voltage test, impressed voltage } \\
\text { test, open circuit potential test } \\
\text { were conducted as per IS and } \\
\text { ASTM standards. }\end{array}$ & $\begin{array}{l}\text { Chemical resistance test and applied voltage } \\
\text { test conducted on coated specimens revealed } \\
\text { that, coating possesses the necessary corrosion } \\
\text { resistance properties as per standards. } \\
\text { Impressed voltage test results indicate that the } \\
\text { coated rebars prolongs the time required for } \\
\text { craking appreciably as compared to uncoated } \\
\text { specimens. Open circuit potential test revealed } \\
\text { a low corrosion risk for all types of coated } \\
\text { rebars }\end{array}$ \\
\hline$[10]$ & $\begin{array}{l}\text { Phares et al } \\
\text { [2006] }\end{array}$ & $\begin{array}{l}\text { Evaluation of Corrosion } \\
\text { Resistance of Different } \\
\text { Steel Reinforcement Types }\end{array}$ & Evaluation test, Adhesion test. & $\begin{array}{l}\text { From the evaluation test, to measure the } \\
\text { difference in corrosion resistance between } \\
\text { MMFX composite steel. Epoxy coated } \\
\text { reinforcement and uncoated reinforcement in } \\
\text { bridge decks to determine whether MMFX } \\
\text { steel provides corrosion resistance superior to } \\
\text { epoxy coated steel and to determine the } \\
\text { inhibition of corrosion and the rate of corrosion } \\
\text { growth in these three reinforcement materials. }\end{array}$ \\
\hline$[11]$ & $\begin{array}{c}\text { ASTM } \\
\text { Standards G109 } \\
{[1999]}\end{array}$ & $\begin{array}{l}\text { Standard Test method for } \\
\text { determining the effect of } \\
\text { chemical admixtures on } \\
\text { the corrosion of embedded } \\
\text { steel reinforcement in }\end{array}$ & & \\
\hline
\end{tabular}




\begin{tabular}{|c|c|c|c|c|}
\hline & & $\begin{array}{l}\text { concrete exposed to } \\
\text { chloride environments. }\end{array}$ & & \\
\hline [12] & $\begin{array}{l}\text { Lee et al. } \\
\text { [2009] }\end{array}$ & $\begin{array}{c}\text { Corrosion performance of } \\
\text { Electroless Nickel-Plated } \\
\text { Steel }\end{array}$ & Bond strength test & $\begin{array}{c}\text { The electroplating has no significant impact on } \\
\text { steel bond strength. In most cases, Electroless } \\
\text { nickel-plated film showed a reduced corrosion } \\
\text { probability. }\end{array}$ \\
\hline [13] & $\begin{array}{l}\text { IS- 13620: } \\
\text { [1993] }\end{array}$ & $\begin{array}{l}\text { Fusion Bonded Epoxy } \\
\text { Coated Reinforcing Bars }\end{array}$ & $\begin{array}{l}\text { Surface Preparation, and } \\
\text { Application of coating }\end{array}$ & \\
\hline [14] & $\begin{array}{c}\text { ASTM } \\
\text { A775/A775M- } \\
{[1993]}\end{array}$ & $\begin{array}{l}\text { Standard specification for } \\
\text { epoxy-coated reinforcing } \\
\text { bars, American Society for } \\
\text { Testing and Materials. }\end{array}$ & & \\
\hline [15] & $\begin{array}{c}\text { ASTM C-876- } \\
\text { [1999]. }\end{array}$ & $\begin{array}{l}\text { Standard Test Method for } \\
\text { Half-Cell Potentials of } \\
\text { Uncoated Reinforcing } \\
\text { Steel in Concrete }\end{array}$ & Open Circuit Potential Test & \\
\hline
\end{tabular}

\section{MATERIAL PROPERTIES}

\subsection{Selection and Coating for steel}

The metallurgists and electrochemical engineers have developed several methods for cover of steel from corrosion in concrete. the foremost commonly known systems of protection of steel from corrosion in concrete are use of corrosion resistance steel reinforcement bars. Methods developed by Central Electro-Chemical Research Institute (CECRI), as Inhibited Cement Slurry Coating System (Old Method), and Cement-Polymer-Composite Coating System (New Method), Fusion Bonded Epoxy Coated Rebars (FBECR), Hot dip - Galvanizing, Epoxy Phenolic Interpenetrating Polymer Network (IPN) Coating for reinforcing steel, Truncated inhibited slurry cement base coating.

Electroless nickel plating may be a chemical change which reduces nickel ions in solution to nickel metal by chemical reduction. the foremost common reducer used is sodium hypophosphite. It's estimated that sodium hypophosphite is employed in additional than $99 \%$ of all electroless nickel plating and this publication refers only to the utilization of this reducer thanks to rebar corrosion problem, effective additional protective measures must be undertaken within the construction stage itself. the target of this investigation is to switch the surface of the bare steel by electroless nickel coating in three different thickness $(10 \mu, 20 \mu$, and $30 \mu)$ supported the time (half an hour, 1 hour, and $1 \& 1 / 2$ hour). The efficiency of corrosion resistance properties of $10 \mu, 20 \mu$, and $30 \mu$ coated steel were evaluated by conducting circuit potential test, tolerable limit of chloride test, accelerated impressed voltage test and various electrochemical corrosion tests. Methodology for the preparation of Nickel coated steel Briefly following the steps which are involved within the coating process are:

a. Derusting by dipping the rebars in pickling solution (patent no.465/CAL/75) for half-hour ( $\mathrm{pH}$ of the answer is 1.04).

b. Removal from acid tank and dipping in alkaline tank to neutralize and cleaning with potable water for 10 minutes.

c. Cleaning the rod surface with water and dry it for twenty-four hours. The appliance of the coating shall not be unduly delayed and shall commence immediately after completion of surface preparation.

d. Application of first coat of nickel coating $10 \mu$ for half-hour and drying for twenty-four hours.

e. Application of second coat of nickel coating $20 \mu$ for 45 minutes and drying for twenty-four hours.

f. Application of third coat of nickel coating $30 \mu$ for hour and drying for twenty-four hours.

\subsection{Materials used}

The cement used was Ordinary hydraulic cement (53 Grade) conforming to IS 298-1976. The compositions of OPC used are given as in Table 2.

Table 2. Compositions of OPC

\begin{tabular}{cc}
\hline Constituents & Quantity \\
\hline Loss on ignition & $2.60 \%$ \\
$\mathrm{Sio}_{2}$ & $22.14 \%$ \\
$\mathrm{Fe}_{2} \mathrm{O}_{3}$ & $3.35 \%$ \\
$\mathrm{Al}_{2} \mathrm{O}_{3}$ & $11.85 \%$ \\
$\mathrm{CaO}$ & $60.68 \%$ \\
$\mathrm{MgO}$ & $1.30 \%$ \\
\hline
\end{tabular}

Locally available well-graded quarry dust, conforming to Zone-II of IS 383-1970 having relative density 2.68 and fineness modulus 2.70 was used as fine aggregate. Natural granite aggregate having density of $2700 \mathrm{~kg} / \mathrm{m} 3$, relative density 2.7 and fineness modulus 4.33 was used as coarse aggregate. High yield strength deformed $12 \mathrm{~mm}$ diameter bars of Fe 415 grade was used.

\section{EXPERIMENTAL INVESTIGATIONS}

Before conducting the test for the evaluation of protective coatings in steel reinforcement rods, the subsequent criteria are to be taken into accounts:

a. Protective coating should have excellent corrosion resisting properties.

b. Coating shall not affect the bond strength of steel to concrete.

c. Coating shall withstand the handling stresses at site.

d. Aggressiveness of test should meet the relevant ASTM/BIS standards.

The detail of test conducted inorder to guage the performance of coating systems are:

i. Circuit Potential Test

ii. Applied Voltage Test

iii. Accelerated Impressed Voltage Test 


\subsection{Procedure for circuit Potential test}

The experimental investigations are administered at Structural Engineering Laboratory, Anna University, Chennai. Circuit potential test was conducted to guage the performance of coated rebars in nullifying and intrusive the ingress of chloride ions under alternate wetting and drying conditions. This is often a qualitative method of assessing the corrosion condition of the rebar. The potential measurements were administered as per ASTM C876-1991 standard [15]. The tendency of any metal to react with its environments indicated by the potential it develops on contact with the environment. In reinforced structures, concrete act as an electrolyte and therefore the reinforcement will develop a possible counting on the concrete environment, which can vary from place to put. The principle involved during this technique is actually measurement of corrosion potential of rebar with reference to a typical reference electrode, like saturated calomel electrode, copper/copper sulphate electrode, silver/silver electrode etc. due to its good stability, calomel electrodes are widely wont to measure the potential of embedded steel in concrete structures. The steel rebar in concrete structures should be accessible during a few locations for giving electrical connections. Figure 1 shows the circuit potential test ongoing.

The positive terminal of high impedance voltmeter is connected to exposed rebar and negative terminal to reference half-cell. The reference electrode is dipped into the answer and therefore the corresponding potentials are recorded. The observed potential readings are compared with ASTM criteria for corrosion of steel in concrete just in case of uncoated bars, and three thickness coated bars. These are referred as either circuit potential or corrosion potential.

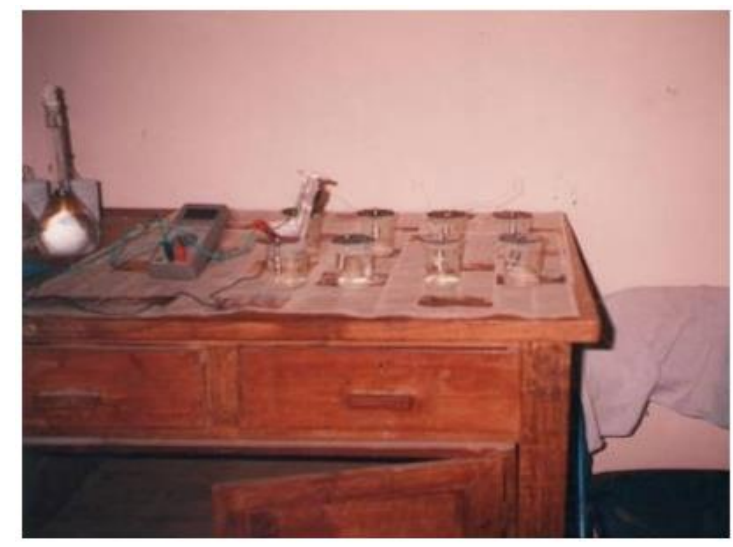

Figure 1. Open Circuit Potential Test in progress

\subsection{Procedure for Applied Voltage}

The effects of electrical and electrochemical stress on the bond of coating to steel and film integrity of the coating were assessed by conducting applied voltage test. This is often an accelerated sort of corrosion test administered as per Indian Standard Code (IS13620 -1993). Applied voltage test is an accelerated test to guage the corrosion resistance of coated rebars in $7 \% \mathrm{NaCl}$ as per ASTM standars. It's a top quality control test for fusion bonded epoxy coated rebar. As per the quality specification, during the primary jiffy there shouldn't be any rust spot on the coated rebar and no hydrogen evolution at the cathode rebar. The corrosion rate for uncoated and coated rebar has been evaluated and compared. The experimental investigations are administered at Structural Engineering Laboratory, Anna University, Chennai.

A non conductive plastic container of size not but 150x150x850mm was used for the test. The container was crammed with $7 \% \mathrm{NaCl}$ solution up to a height of $800 \mathrm{~mm}$. The coated rebars were suspended vertically soon have a clearance of $25 \mathrm{~mm}$ from rock bottom, $40 \mathrm{~mm}$ from the edges and $40 \mathrm{~mm}$ in between the rods. One reinforcement bar was connected as anode with the terminal of D.C power source, other reinforcement bar was connected as cathode. A possible of $2 \mathrm{~V}$ was impressed in-between the 2 electrodes up to a period of hour using suitable D.C power supply. The coating failure as evidenced by the evolution of hydrogen gas at the cathode or the looks of corrosion products of iron at the anode was monitored during the trial period. A saturated calomel electrode with saturated K-Dur 20 as electrolyte and salt bridge made from agar-agar was used for measuring reference electrode potential as shown in Figure 2.

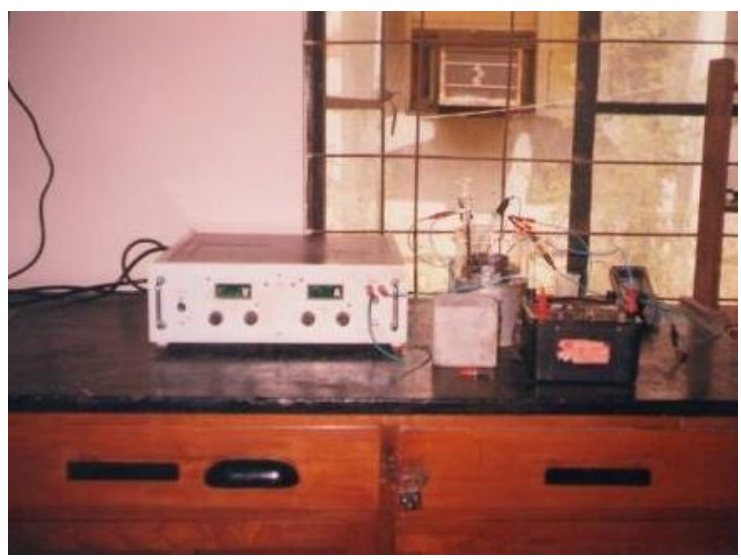

Figure 2. Applied voltage test in progress

The potential measurements were observed at every 5 minutes interval during the trial period using high impedance multitmeter. The present development was also monitored at regular intervals. During the hour of testing no coating failure was observed by evolution of hydrogen gas at the cathode or by the looks of corrosion product at the anode surface.

\subsection{Procedure for Impressed Voltage Test}

Impressed voltage test is an accelerated corrosion test administered to assess the performance of coated rebars under accelerated electrochemical corrosion conditions. The test was administered as per the procedure prescribed by the structural engineering research centre (SERC), Chennai, and Central Electrochemical Research Institude (CECRI), Karaikudi, India, followed by the specifications of Indian Standard Code (IS13620-1993) [13] and American Standard Code (ASTM A775/ A775M-95) [14]. The test specimen comprises of $75 \mathrm{~mm}$ diameter and $100 \mathrm{~mm}$ height concrete cylinder, $12 \mathrm{~mm}$ diameter and $75 \mathrm{~mm}$ length coated rebars were centrally embedded such it gives a transparent cover of $25 \mathrm{~mm}$ from all the edges. The coated rebar act as working electrode and therefore the top surface was soldered with $14 \mathrm{~mm}$ gauge wire. Both top and bottom surfaces were sealed with epoxy material. the highest and bottom surfaces of the concrete specimens were also sealed with epoxy coating so on allow chloride ingress from the edges to duplicate site conditions. The chloride ions migrate through the concrete and to induce 
corrosion in an accelerated manner. The time taken for chloride ions to migrate depends on the entire resistance of concrete and therefore the amount of corrosion will depend upon the induced current. Figure 3 shows the test found out ongoing.

The variation of current was recorded with time. a pointy rise in current indicates the onset of corrosion. The time taken for initial crack is taken into account as a measure of the relative against chloride permeability and reinforcement corrosion. Typical current time relationship for ferroconcrete specimens tested under an applied positive potential of $12 \mathrm{~V}$ Vs SCE.

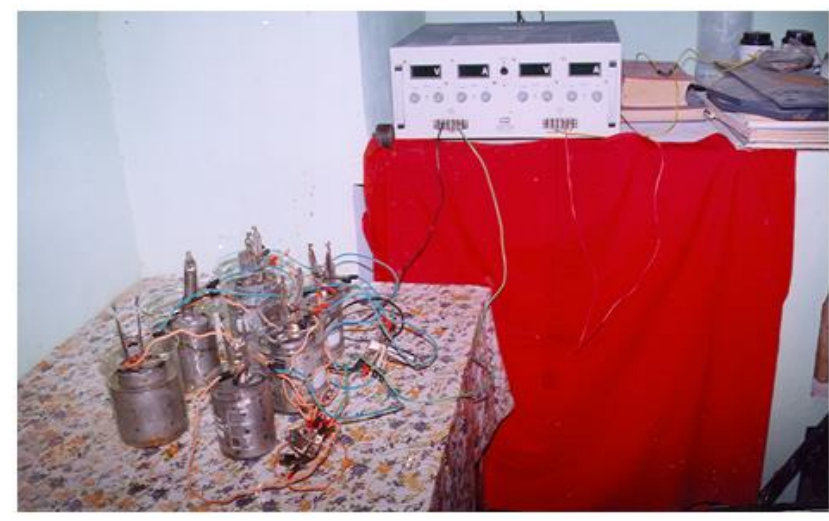

Figure 3. Impressed voltage tests in progress

\subsection{Metal Loss Determination}

In the metal loss determination technique the load loss of reinforcing steel thanks to corrosion is employed to assess the magnitude of concrete deterioration. The reinforcing steel is faraway from the concrete, cleaned then weighed to calculate the metal loss. The metal loss data are then converted into corrosion rate expressed in mmpy (Milli Meter per Year) units.

\subsection{Determination of free chloride contents}

After testing core samples were collected. The core samples (inclusive of fine and coarse aggregates) collected from $75 \mathrm{~mm}$ depth and $12 \mathrm{~mm}$ dia cylindrical cubes also because the cement grout were crushed mechanically and powdered samples were made. Then $50 \mathrm{gm}$ of powdered sample was shaken with $100 \mathrm{ml}$ of water during a conical flask employing a microid flask shaker for one hour. The extract was then filtered through a whatsman paper no 42. The extract prepared from the powdered samples was then analyzed for free of charge chloride content. 20cc of filter solution was taken and free chloride was estimated by standard nitrate titration using potassium chromate as an indicator.

\subsection{Bending test}

The bending test is employed to guage the effective adhesion of the coated substance on the rebar surface. The effective bond adhesion should be formed on the rebar surface and it's essential for reliable future performance of the coated steel rebar in concrete structures. The effective bond adhesion only increases the corrosion resistance property of the steel rebar and may be maintained the right activation round the steel even under the presence of tolerable limits of aggressive ions.
CTD rebars of size $60 \mathrm{~mm}$ long and $12 \mathrm{~mm}$ dia were defrosted during a standard pickling acid dried, and degreased with trichloroethylene. The electroless Ni plating was applied on the pickled surface of the rebars. The varied coating thickness of $10 \mu, 20 \mu$, and $30 \mu$ was applied on the defrosted rebars. After a selected period, the coated rebars were subjected to guage the adhesion by means of bending test. Coated rebars were positioned over the bar bending table such two longitudinal protrustations are placed during a plane perpendicular to the mandrel radius and rebar is kept at a equilibrium of $24 \pm 20 \mathrm{c}$. $10 \mathrm{~mm}$ length of the coated rebar was fixed with the bending guide element. Then the opposite end of the coated rebar was fixed with the bending lever and applied the force to bend at 90oc. The experiment was simultaneously repeated for the opposite specimens. The surface was observed to seek out out any peal of the coated element within the corresponding element respectively.

\subsection{Scanning microscope}

The coatings are analyzed by scanning microscope (SEM) and energy-dispersive x-ray spectroscope (EDX), which unravel the coatings localized morphology and elemental distributions at the microscopic level respectively. Scanning microscope (SEM, JOEL model, JSM make, Model 6380LA) is employed to watch the surface morphology of EN coating and the basic variations within the coating low-carbon steel bar is estimated by Energy Dispersive Xray analysis (EDX) which is attached with SEM. The EDX data are then obtained with a micro-analytical unit that featured the power to detect the tiny variations of chemical element content. EDX attachment is completed in conjunction with SEM for the study of the chemical analysis and therefore the composition of the deposit in terms of the share of Nickel, Sulphur, and Carbon within the coating.

\section{RESULTS AND DISCUSSIONS}

\subsection{Circuit potential test}

Table 3. Guidelines for Probability of corrosion Based on Potential as per ASTM C876-1991

\begin{tabular}{|c|c|c|}
\hline $\begin{array}{l}\text { Potential, } \mathbf{m V} \\
\text { versus } \mathrm{SCE}\end{array}$ & $\begin{array}{c}\text { Potential, mV Vs } \\
\text { Copper/ Copper } \\
\text { sulphate }\end{array}$ & $\begin{array}{l}\text { Probability of } \\
\text { corrosion }(\%)\end{array}$ \\
\hline $\begin{array}{c}\text { More -ve than } \\
-475\end{array}$ & More -ve than -500 & Severe corrosion \\
\hline $\begin{array}{c}\text { More -ve than } \\
-275\end{array}$ & More - ve than -350 & $\begin{array}{c}\text { High risk of } \\
\text { corrosion) }(>90 \%)\end{array}$ \\
\hline $\begin{array}{l}\text { Between }-275 \\
\quad \text { to }-125\end{array}$ & Between $-350 \&-200$ & $\begin{array}{l}\text { Intermediate } \\
\text { corrosion risk } \\
\text { (Uncertain) }\end{array}$ \\
\hline $\begin{array}{c}\text { More +ve than } \\
-125\end{array}$ & More +ve than -200 & $\begin{array}{l}\text { Low corrosion risk } \\
\qquad(<5 \%)\end{array}$ \\
\hline
\end{tabular}

Open circuit potential (OCP) measurement readings were recorded to verify the surface areas of the corroded steel and to match the corrosion potentials of steel embedded in various specimens. The potential values were measured altogether days. Consistent with ASTM when OCP is above $-125 \mathrm{mV}$, there's but $5 \%$ probability that reinforcement may corrode. If the potential is between $125 \mathrm{mV}$ to $-275 \mathrm{mV}$ saturated calomel electrodes (SCE), 
corrosion probability is uncertain. Corrosion probability could also be above $-275 \mathrm{mV}$ to $-475 \mathrm{mV}$ (SCE). As per ASTM C876-1991 [15] standards the probability of reinforcement corrosion is given within the Table 3 and therefore the observations at the top of exposure period as shown in Table 4. At the top of trial period, the condition of rebar inside the answer was examined to seek out the extension of corrosion.

Table 4. Observation on uncoated and coated steel bars at the end of exposure period in potential test

\begin{tabular}{|c|c|c|c|}
\hline S.No & $\begin{array}{l}\text { Type of } \\
\text { coating }\end{array}$ & $\begin{array}{c}\text { Visual examination of } \\
\text { rebar from broken } \\
\text { specimen }\end{array}$ & Interpretation \\
\hline 1 & $\begin{array}{c}\text { Mild } \\
\text { steel bar }\end{array}$ & $\begin{array}{l}\text { Localised patchy rusted } \\
\text { area. Few visible } \\
\text { corrosion pits }\end{array}$ & $\begin{array}{l}\text { Severe } \\
\text { corrosion risk }\end{array}$ \\
\hline 2 & $\begin{array}{l}\text { Coated } \\
\text { steel } \\
(10 \mu)\end{array}$ & $\begin{array}{l}\text { Localised patchy rusted } \\
\text { area. No corrosion pits. } \\
\text { Few rust spots }\end{array}$ & $\begin{array}{l}\text { High ( } 90 \% \\
\text { corrosion risk) }\end{array}$ \\
\hline 3 & $\begin{array}{l}\text { Coated } \\
\text { steel } \\
(20 \mu)\end{array}$ & No rust spots & $\begin{array}{l}\text { Low corrosion } \\
\text { risk }\end{array}$ \\
\hline 4 & $\begin{array}{l}\text { Coated } \\
\text { steel } \\
(30 \mu)\end{array}$ & No rust spots & $\begin{array}{l}\text { Low corrosion } \\
\text { risk }\end{array}$ \\
\hline
\end{tabular}

They are preferred frequently on rebar concrete structures because they identify the zones with different corrosion probability. The overall test method is described within the ASTM C876-1991 standard. This standard states that the potentials above $-200 \mathrm{mV}$ versus Copper/Copper Sulphate Electrode (CSE) the probability of corrosion is extremely less (less than $5 \%$ ) while below $-350 \mathrm{mV}$, corrosion is extremely portable (greater than 95\%). Bare low-carbon steel showed active potentials throughout the trial period of 30 days. A minimum potential of $-332 \mathrm{mV}$ and a maximum potential of $778 \mathrm{mV}$ were measured in cement extract without $\mathrm{NaCl}$ and therefore the other hand a minimum potential of $-482 \mathrm{mV}$ and a maximum potential of $-760 \mathrm{mV}$ were measured in cement extract with $3.5 \% \mathrm{NaCl}$ as shown in Figure 4.

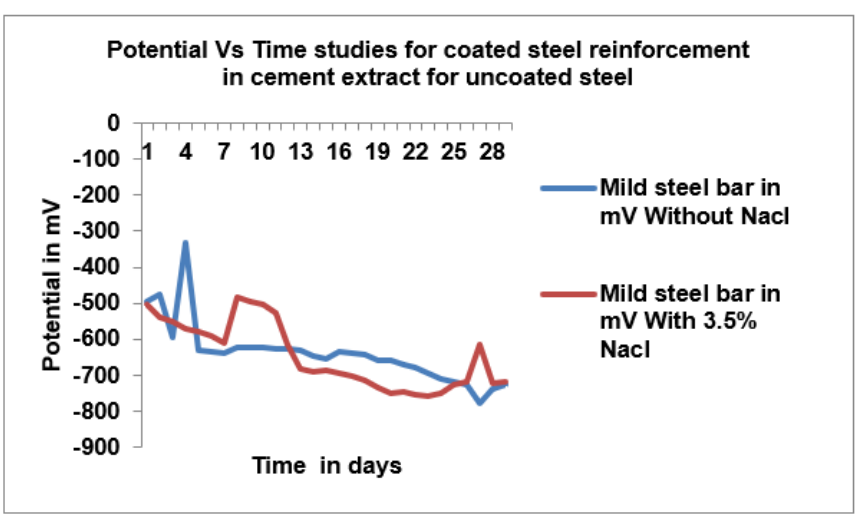

Figure 4. Potential Vs Time studies for bare steel rebars in cement extract

$10 \mu$ coated steel showed very low passive potentials up to 10 days of exposure. A minimum potential of $-249 \mathrm{mV}$ and a maximum potential of $-518 \mathrm{mV}$ were measured in cement extract without $\mathrm{NaCl}$ and the other hand a minimum potential of $-454 \mathrm{mV}$ and a maximum potential of $-603 \mathrm{mV}$ were measured in cement extract with $3.5 \% \mathrm{NaCl}$ as shown in
Figure 5. $20 \mu$ and $30 \mu$ Coated steel almost showed passive potentials in the range of $-422 \mathrm{mV}$ to $-557 \mathrm{mV}$ in the absence of $\mathrm{NaCl}$ and the other hand the passive potential shows potentials in the range of $-410 \mathrm{mV}$ to $-633 \mathrm{mV}$ in the presence of $\mathrm{NaCl}$ are shown in Figure 6 and 7. This is due to the formation of $\mathrm{Ni}$ $(\mathrm{OH})_{2}$, stable potentials were measured.

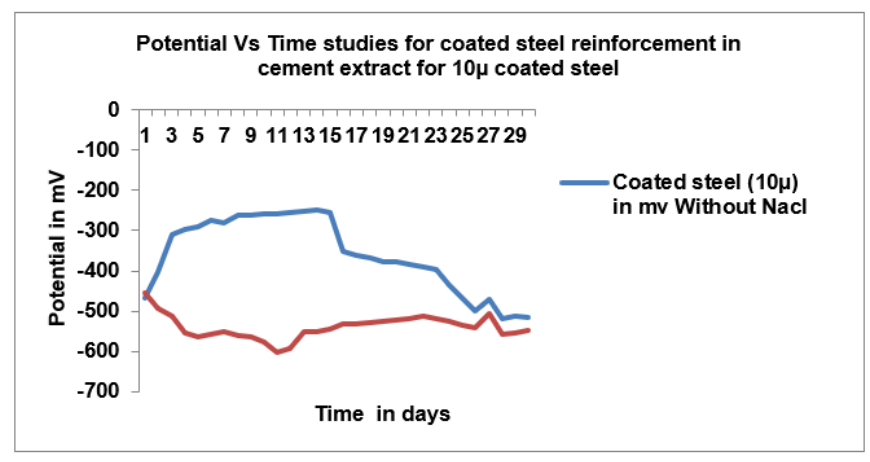

Figure 5. Potential Vs Time studies for $10 \mu$ coated steel rebars in cement extract

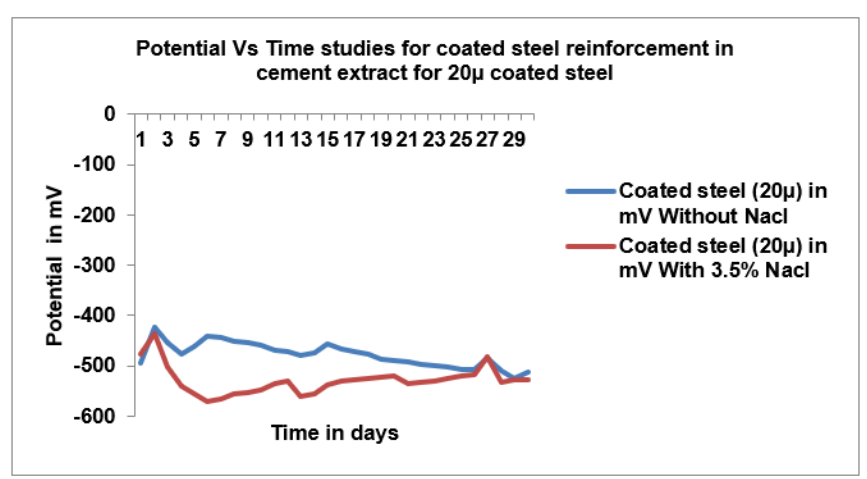

Figure 6. Potential Vs Time studies for $20 \mu$ coated steel rebars in cement extract

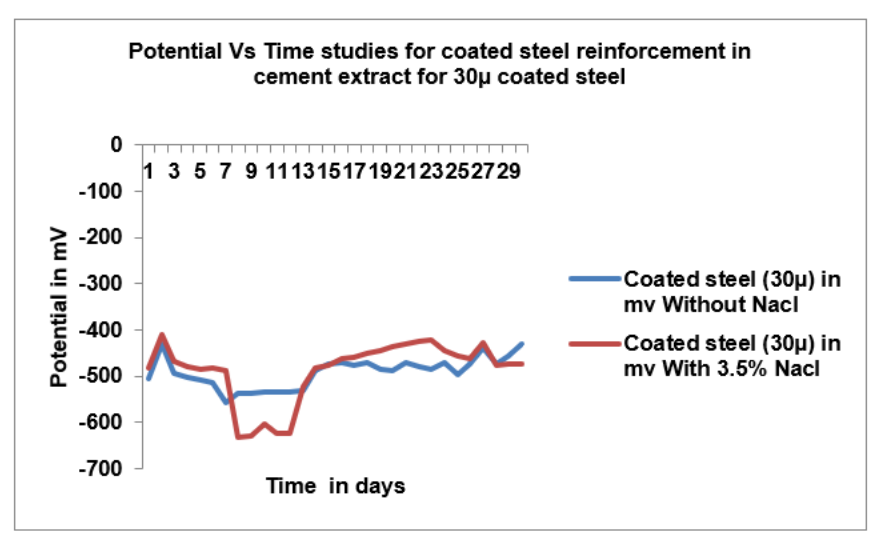

Figure 7. Potential Vs Time studies for $30 \mu$ coated steel rebars in cement extract

\subsection{Experimental impedance time setup}

The polarization resistance $r_{p} K \Omega$ values calculated for coated steel with $10 \mu, 20 \mu$, and $30 \mu$ thicknesses in pure cement extract as shown in Figure 8 and cement extract with $3.5 \% \mathrm{NaCl}$ medium as shown in Figure 9, the $r_{p}$ values recorded initially in pure cement extract were found to be $21.56,23.49$, and $19.43 \mathrm{~K} \Omega$ for $10 \mu, 20 \mu$, and $30 \mu$ thicknesses respectively. These data indicated that in aggressive chloride 
medium the $r_{p}$ values considerably decreased. After one month of exposure in pure cement extract the $r_{p}$ values actually doubled in 53.96, 63.76, and $46.93 \mathrm{~K} \Omega$ for $10 \mu, 20 \mu$, and $30 \mu$ thickness. These data indicated that in pure cement extract nickel reacts with $\mathrm{Ca}(\mathrm{OH})_{2}$ present in cement extract and form $\mathrm{Ni}(\mathrm{OH})_{2}$. This stable compound considerably increased the polarization resistance. In case of cement extract $+3.5 \% \mathrm{NaCl}$ medium the $r_{p}$ values showed an increasing trend. This interesting behavior was observed due to the stability of $\mathrm{Ni}$ $(\mathrm{OH})_{2}$ even in the presence of aggressive chloride medium.

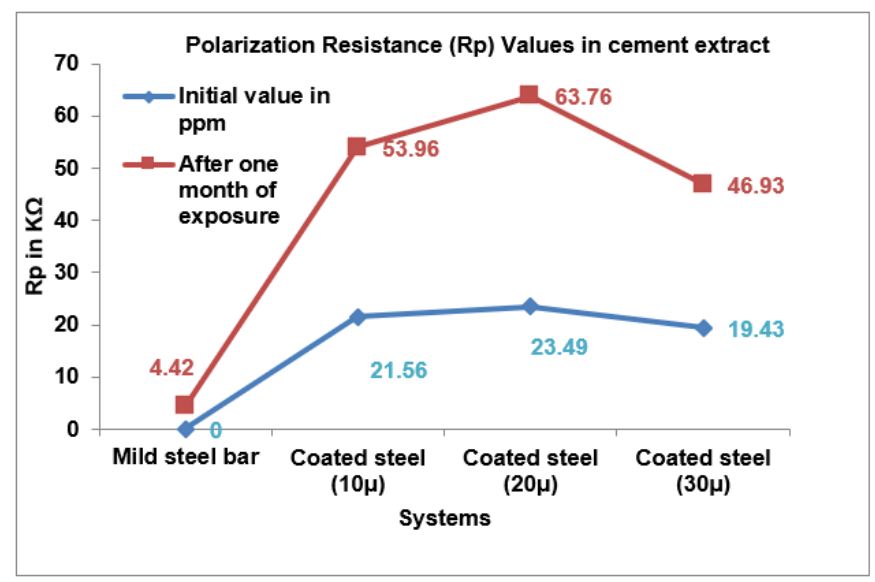

Figure 8. Polarization resistance $\operatorname{Rp}$ values $(\mathrm{k} \Omega)$ in pure cement extract

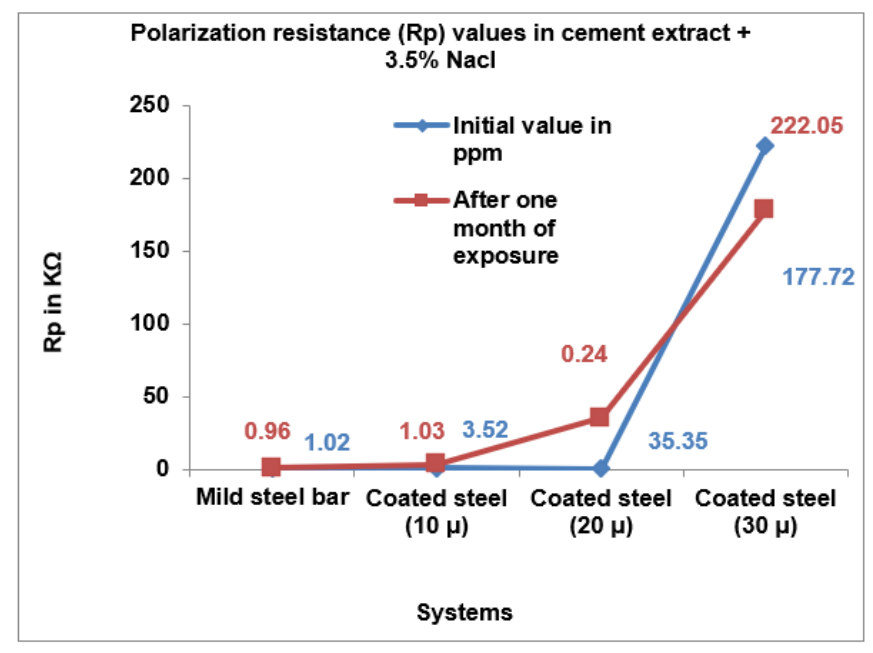

Figure 9. Polarization resistance rp values $(\mathrm{k} \Omega)$ in pure cement extract with $3.5 \% \mathrm{NaCl}$

\subsection{Gravimetric Weight loss measurement}

Initially weighed the bare mild steel and coated steel with $10 \mu, 20 \mu$, and $30 \mu$ thickness was exposed to cement extract for 30 days of exposure. After, the specimens were taken out, cleaned in, dried and weighed. From the weight loss, corrosion rate was calculated using the formula,

\section{Corrosion rate $=$}

$$
\frac{(87.6 \mathrm{x} \text { Weight loss in } \mathrm{mg})}{\text { (Area in } \left.\mathrm{cm}^{2} \mathrm{x} \text { time in hours } \mathrm{x} \text { density in } \mathrm{g} / \mathrm{cc}\right)}
$$

The corrosion rate of bare mild steel and coated steel after 30 days of exposure in cement extract are shown in Figure 10. In the absence of Nacl, bare mild steel showed the corrosion rate of $0.03902 \mathrm{mmpy}$ and the coated steel specimen showed slight decrease in corrosion rate. The corrosion rate values observed for the corresponding $10 \mu, 20 \mu$, and $30 \mu$ coating thickness were found to be $0.03852,0.03529,0.03524$ mmpy respectively. These data clearly showed that increase in coating thickness decreased the corrosion rate markedly. On the other hand in the presence of $3.5 \% \mathrm{Nacl}$, the corrosion rate of bare steel $0.03759 \mathrm{mmpy}$ and the coated steel specimen showed slight decrease in corrosion rate. The corrosion rate values observed for the corresponding $10 \mu, 20 \mu$, and $30 \mu$ coating thickness were found to be $0.03616,0.03600,0.03542$ mmpy respectively. These data also clearly showed that increase in coating thickness decreased the corrosion rate markedly.

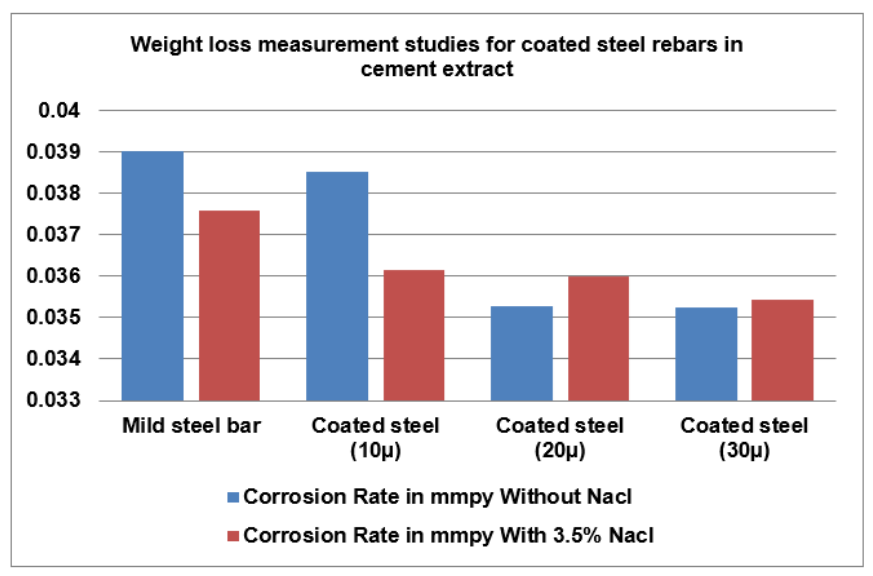

Figure 10. Weight loss measurement studies for coated steel rebars in cement extract

\subsection{Applied voltage test}

At the end of exposure period, the observation of hydrogen gas evolution for coated and uncoated steel rebar as shown in Table 5.

Table 5. Observations at the end of exposure period for

\begin{tabular}{|c|c|c|}
\hline $\begin{array}{c}\text { Type of coating } \\
\text { (Electroless nickel } \\
\text { coating) }\end{array}$ & $\begin{array}{c}\text { Anode } \\
\text { (At the end of one } \\
\text { hour) }\end{array}$ & $\begin{array}{c}\text { Cathode } \\
\text { (During the } \\
\text { test period) } \\
\end{array}$ \\
\hline Bare Mild steel & $\begin{array}{c}\text { Innumerable rust } \\
\text { spots }\end{array}$ & $\begin{array}{c}\text { Vigorous } \\
\text { evolution of } \\
\text { hydrogen gas }\end{array}$ \\
\hline $10 \mu$ coated steel & $\begin{array}{l}\text { No corrosion } \\
\text { products of iron }\end{array}$ & $\begin{array}{c}\text { No evolution of } \\
\text { hydrogen gas }\end{array}$ \\
\hline $20 \mu$ coated steel & $\begin{array}{l}\text { No corrosion } \\
\text { products of iron }\end{array}$ & $\begin{array}{c}\text { No evolution of } \\
\text { hydrogen gas }\end{array}$ \\
\hline $30 \mu$ coated steel & $\begin{array}{l}\text { No corrosion } \\
\text { products of iron }\end{array}$ & $\begin{array}{c}\text { No evolution of } \\
\text { hydrogen gas }\end{array}$ \\
\hline
\end{tabular}
coated and uncoated steel rebars in applied voltage test

4.4.1 Gravimetric Weight loss measurement for Applied Voltage Test:

Initially weighed the bare steel and coated steel with $10 \mu$, $20 \mu$, and $30 \mu$ thickness for 60 minutes of exposure. After, the specimens were taken out, cleaned in, dried and weighed. From the weight loss, corrosion rate was calculated using the formula, Corrosion rate $=(87.6 \mathrm{x}$ Weight loss in $\mathrm{mg}) /($ Area in $\mathrm{cm}^{2} \mathrm{x}$ time in hours $\mathrm{x}$ density in $\mathrm{g} / \mathrm{cc}$ ). The corrosion rate of bare mild steel and $10 \mu, 20 \mu$, and $30 \mu$ coated steel after 60 minutes of exposure in $7 \% \mathrm{NaCl}$ are shown in Figure 11. The 
bare mild steel showed the corrosion rate of $0.23 .0667 \mathrm{mmpy}$ and the coated steel specimen showed 3 times decrease in corrosion rate. The corrosion rate values observed for $10 \mu$, $20 \mu$, and $30 \mu$ coating thickness were found to be 8.6449 , $8.5852,8.0128 \mathrm{mmpy}$ respectively. These data clearly showed that increase in coating thickness decreased the corrosion rate markedly. From the above result, it was concluded as the corrosion rate decreased to 3 times when compared to bare mild steel.

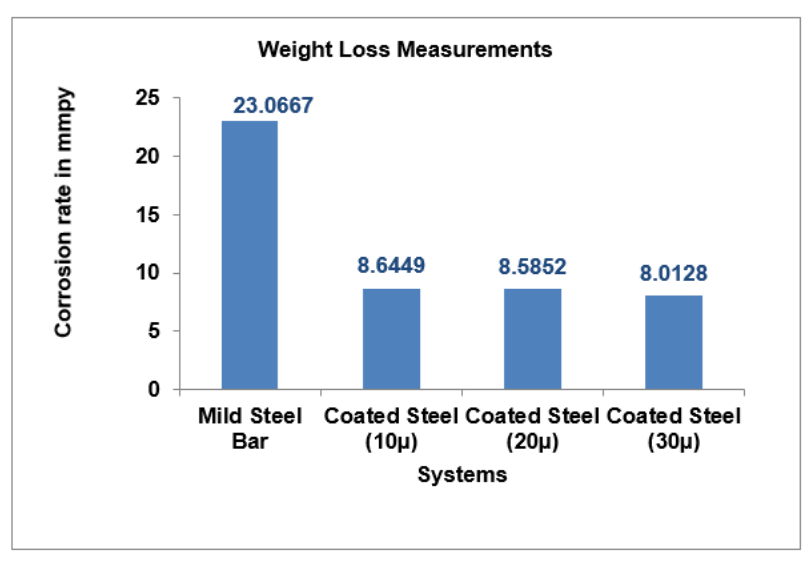

Figure 11. Welght loss measurements in Applied Voltage test

\subsection{Impressed voltage test}

\subsubsection{Time taken for initial crack}

The time taken for initial crack for bare mild steel was observed at 23.45 hours. $10 \mu$ and $20 \mu$ coated steel showed higher values of time taken for initial crack. For example $10 \mu$, $20 \mu$ coated steel showed 28.45 hours and 47.30 hours as time taken for initial crack. These data indicated that $20 \mu$ coated steel actually doubled the time taken for initial crack was found to be 25.00 hours. Maximum current flow data showed $60 \mathrm{~mA}$ for bare mild steel. On the other hand the maximum current flow considerably decreased for coated steel. For example $10 \mu, 20 \mu, 30 \mu$ coated steel showed $53 \mathrm{~mA}, 45 \mathrm{~mA}$, $47 \mathrm{~mA}$ respectively. These data showed that increasing the coating thickness from $10 \mu$ to $30 \mu$ decreased the magnitude of current flow. The amount of chloride present was expressed in terms of ppm (Parts per Million) on the basis of weight of sample taken for analysis as shown in Figure 12.

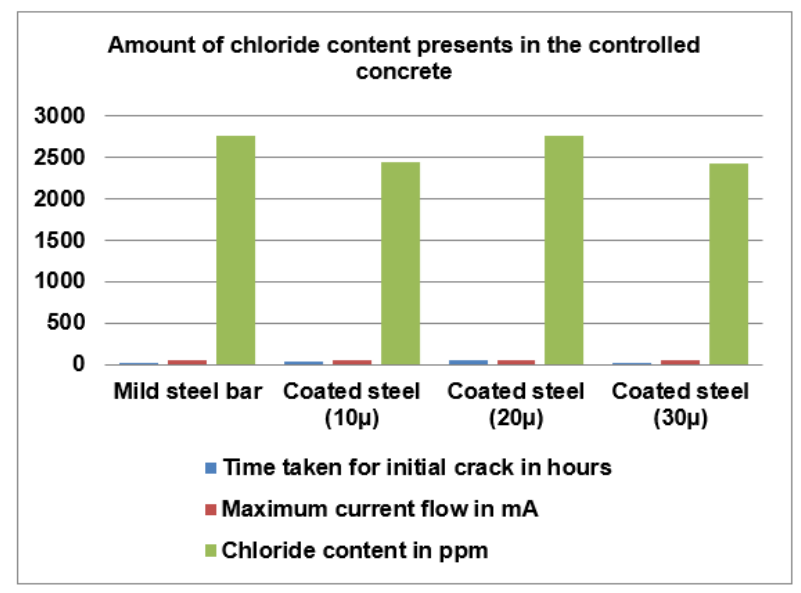

Figure 12. Amount of Chloride present in the controlled concrete
- Time taken for initial crack was doubled for $20 \mu$ coated steel.

- $\quad$ The magnitude of the current flow was also found to be the least at $20 \mu$ coated steel.

- For $20 \mu$ coated steel, 2 times decrease in corrosion rate was observed when compared to bare mild steel.

\subsection{Weight loss measurements}

Corrosion rate of bare steel and coated steel embedded in cylindrical concrete revealed that bare mild steel showed 0.09670 mmpy. On the other hand $10 \mu, 20 \mu$ coated steel considerably decreased the corrosion rate of coated steel. For example $10 \mu, 20 \mu$ coated steel showed $0.09207 \mathrm{mmpy}$, and 0.04519 mmpy respectively. These data indicated that $20 \mu$ coated steel showed a very high corrosion rate of 0.09987 mmpy are shown in Figure 13.

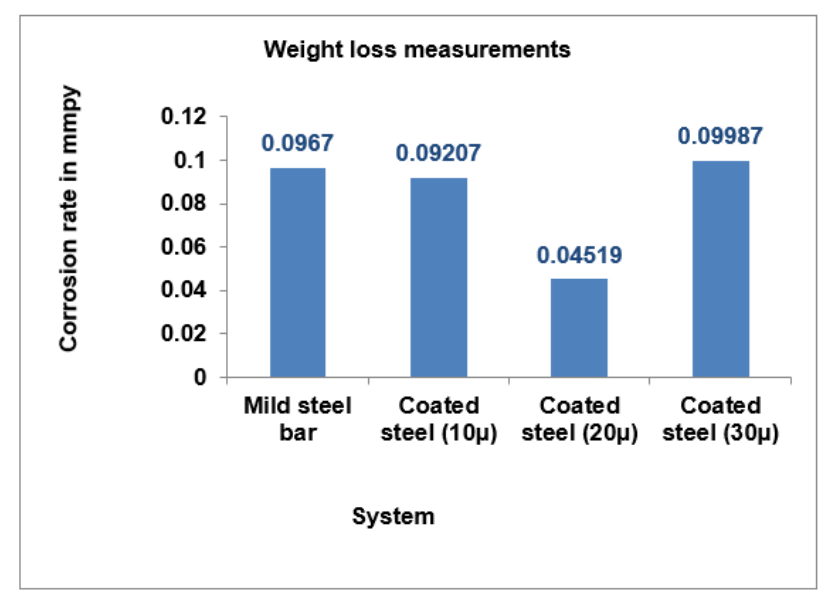

Figure 13. Weight loss measurement in Impressed voltage test

\subsection{SEM test}

SEM test is used to study the surface texture of the specimen [16-29]. To explore the microstructure, composition and the performance of $10 \mu, 20 \mu$, and $30 \mu$ coatings with relatively uniform top surface are selected to deposit EN coatings in mild steel reinforcement bar. These selected coatings are then analysed by SEM and EDX, which unravel the coatings, localized morphology and elemental distributions are shown in Table 6 at the microscopic level respectively. The properties of the EN depositions are attributed to their microstructure characteristics. The details of the structures of EN deposits are not clear but it has been reported to be either crystalline, amorphous, or both. By Studying the microstructure of the deposits helps us to understand the mechanism of deposition and also to evaluate the properties of deposition. The surface morphology of the coating is observed by SEM and their coated surface of $10,20 \mu, 30 \mu$ is shown in Figure 14-16.

Table 6. Elemental Distributions

\begin{tabular}{ccccc}
\hline S.No & System & Element & Weight \% & Atom \% \\
\hline \multirow{3}{*}{1} & \multirow{2}{*}{$10 \mu$} & $\mathrm{C}$ & 0.22 & 1.04 \\
& & $\mathrm{~S}$ & 0.36 & 0.64 \\
& & $\mathrm{Ni}$ & 99.43 & 98.32 \\
2 & \multirow{2}{*}{$20 \mu$} & $\mathrm{O}, \mathrm{Cl}$ & $2.52,0.34$ & $8.59,0.52$ \\
& & $\mathrm{~S}$ & 0.78 & 1.33 \\
& & $\mathrm{Ni}$ & 96.36 & 89.56
\end{tabular}




\begin{tabular}{|c|c|c|c|c|}
\hline \multirow{3}{*}{3} & & C & 0 & 0 \\
\hline & $30 \mu$ & $\mathrm{S}$ & 0.43 & 0.79 \\
\hline & & $\mathrm{Ni}$ & 99.57 & 99.21 \\
\hline
\end{tabular}
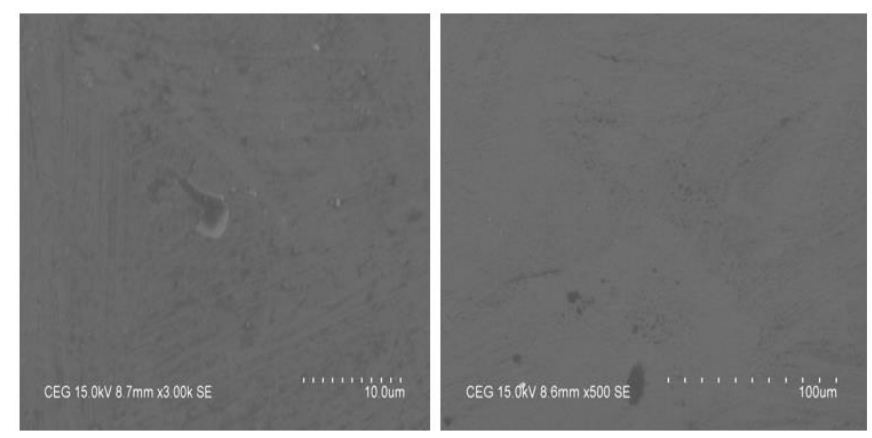

Figure 14. SEM microphotograph of surface of EN coating in $10 \mu$ after exposure of test electrolyte

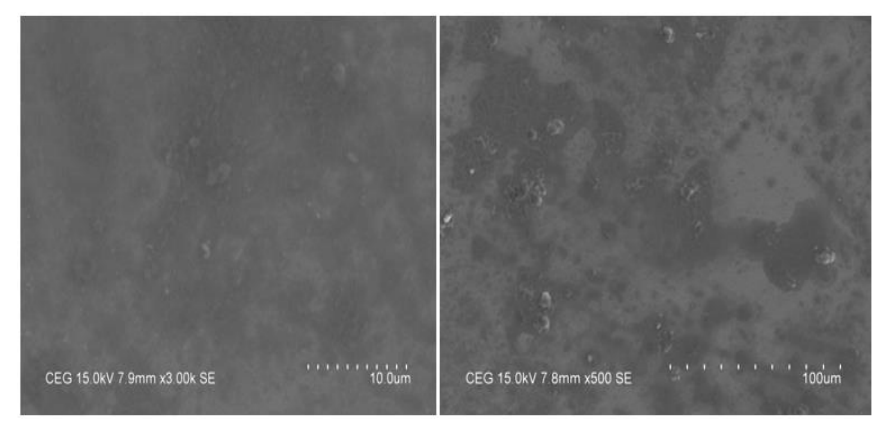

Figure 15. SEM microphotograph of surface of EN coating in $20 \mu$ after exposure of test electrolyte
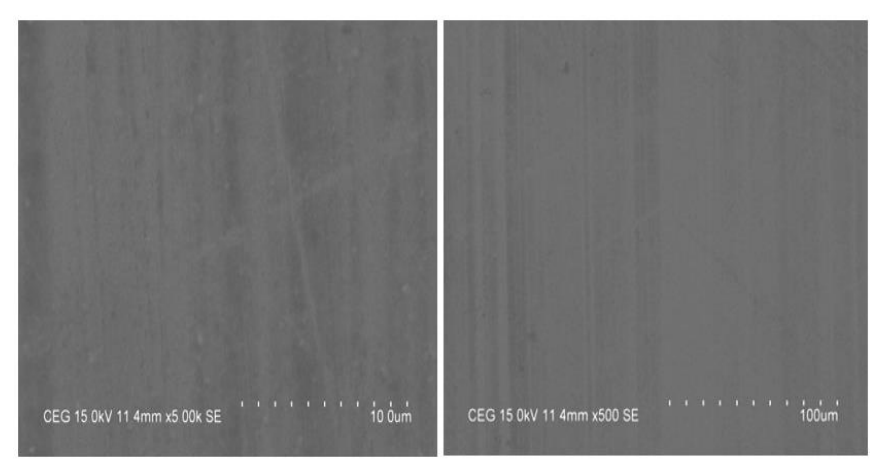

Figure 16. SEM microphotograph of surface of EN coating in $30 \mu$ after exposure of test electrolyte

Figure 14 shows the patches slightly deposit on the coated material and the grains formed above the surface. In Figure 15, it can be seen that some scratches and residual contaminants are remained on the $20 \mu$ coated steel. These defects are from the polishing process are typical and may provide localized sites for corrosion to initiate in natural environment. The good $\mathrm{Ni}$ coating featured very dense and homogeneous surface microstructure whereas the poor Ni coating exhibited dense yet heterogeneous microstructure. In contrast, the worst $\mathrm{Ni}$ coating exhibited very loose deposition of particles and the presence of contaminants in the deposited surface layer. On the other hand, the electroless deposition of $\mathrm{Ni}$ coatings in $10 \mu$ and $30 \mu$ was successful, since the surface layer was dominated by the Ni element. The EDX was performed to study the composition of the coating. The EDX analysis shows that the electroless coating contains $98.32 \% \mathrm{Ni}, 0.64 \% \mathrm{~S}$ and $1.04 \% \mathrm{C}$ in $10 \mu$, whereas $89.56 \% \mathrm{Ni}, 1.33 \% \mathrm{~S}, 8.59 \% \mathrm{O}$ and $0.52 \% \mathrm{Cl}$ are deposit in $20 \mu$ and $99.21 \% \mathrm{Ni}$ and $0.79 \% \mathrm{~S}$ are present in $30 \mu$. The EDX spectra of the coating surface are shown in Figure 17
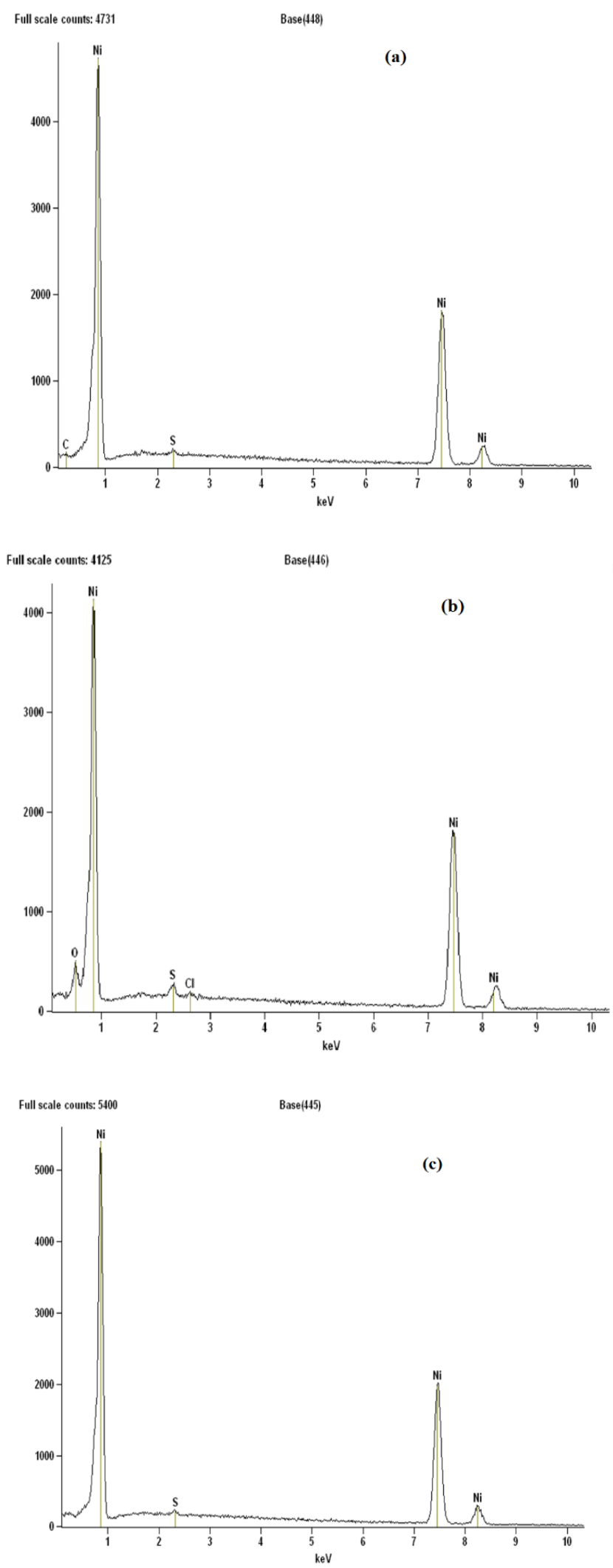

Figure 17. Shows the EDX of EN coating in (a) $10 \mu$; (b) $20 \mu$; (c) $30 \mu$ coated mild steel reinforcement bar 


\section{CONCLUSIONS}

In this research part, the experimental study was conducted to investigate the behaviour of the nickel coated steel rebars as:

- The potential time studies carried out for coated steel in cement extract showed stable potentials in the range of $-400 \mathrm{mV}$ to $500 \mathrm{mV}$ Vs SCE (-160 to $-260 \mathrm{mV}$ Vs SHE). In presence of aggressive chloride $3.5 \% \mathrm{NaCl}$ medium, also the coated steel showed stable potentials in the range of $-450 \mathrm{mV}$ to $-550 \mathrm{mV}$ Vs SCE $(-210 \mathrm{mV}$ to $-410 \mathrm{mV} \mathrm{Vs}$ SHE). These data confirmed the stability of the coating even in the presence of the aggressive chloride medium during one, month exposure.

- The electrochemical impedance spectroscopy studies carried out for coated steel in cement extract showed that the Rp values increased 2 times compared to the critical values. In presence of aggressive chloride medium also, the $\mathrm{Rp}$ values showed an increasing trend due to the stability of the $\mathrm{Ni}(\mathrm{OH})_{2}$ passive film.

- The corrosion rate values calculated from gravimetric method revealed heat even in the presence and absence of chloride only a slight variation in common rate was observed due to the formation of stable nickel compounds at the surface.

- $2 \mathrm{~V}$ accelerated applied voltage test results showed a 3 times decrease in corrosion rate for coated steel when compared to bare mild steel.

- $12 \mathrm{~V}$ accelerated impressed voltage test results indicates that

- Time taken for initial crack was doubled for $20 \mu$ coated steel.

- The magnitude of the current flow was also found to be the least at $20 \mu$ coated steel.

- For $20 \mu$ coated steel, 2 times decrease in corrosion rate was observed when compared to bare mild steel.

- The coated bar did not fail during one hour applied voltage test and passes the requirements on ASTM standards.

- Impressed voltage test results showed an increase in cracking resistance time for coated bars of the order of 3 times as compared to uncoated bars in control irrespective of the type of bar.

- The coating damage did not contribute any appreciable influence on the cracking resistance behaviour for both control and uncontrolled concrete.

- $12 \mathrm{~mm}$ coated steel was bending at $180^{\circ}$ with mandrel diameter $280 \mathrm{~mm}$ for 45 seconds. $10 \mu, 20 \mu, 30 \mu$ coated steel showed no cracking of coating.

- The mild steel rebars coated by the Ni featured the highest noise resistance and lowest corrosion rate over the one month exposure, followed by the mild steel rebars coated by the Ni.

- The noise data confirm that the Ni coatings greatly enhanced the corrosion resistance of the steel substrate.

- This study lays the groundwork for developing a costeffective method to protect steel bar for concrete as well as industrial applications.

- The electrochemical experiments proved that the electroless Ni coatings significantly improved the steel substrate and led to corrosion behaviour.

- The coatings on the rebar surface also greatly reduced the risk of pitting corrosion and crevice corrosion in the basic and salty environment.

\section{REFERENCES}

[1] Abner, B., Riddell, G.E. (1950). Nickel plating by chemical reduction. U.S. Patent No. 2, 532, 283. Washington, DC: U.S. Patent and Trademark Office. Journal of Research of the National Bureau of Standards, 37(1): 31- 34.

[2] Rengaswamy, N.S., Srinivasan, S., Balasubramanian, T. M. (1988). Inhibited and sealed cement slurry coating of steel rebar-A state of art report. Transactions of SAEST, 23(2-3):

163-173. http://cecri.csircentral.net/id/eprint/3195

[3] Singh, D.D.N., Ghosh, R. (2006). Electroless nickelphosphorus coatings to protect steel reinforcement bars from chloride induced corrosion. Surface and Coatings Technology, 201(1-2):

90-101.

https://doi.org/10.1016/j.surfcoat.2005.10.045

[4] Pyc, W.A., Weyers, R.E., Sprinkel, M.M. (1998). Corrosion protection performance of corrosion inhibitors and epoxy-coated reinforcing steel in a simulated concrete pore water solution (No. VTRC-98-R42). Virginia Transportation Research Council. 40.

[5] Freedman, S. (1998). Corrosion resistance of reinforcement in architectural precast concrete. PCI journal, 43(1): 12-19. https://doi.org/10.15554/pcij.01011998.12.19

[6] Ahmad, S. (2009). Techniques for inducing accelerated corrosion of steel in concrete. Arabian Journal for Science and Engineering, 34(2): 95.

[7] El Maaddawy, T.A., Soudki, K.A. (2003). Effectiveness of impressed current technique to simulate corrosion of steel reinforcement in concrete. Journal of materials in civil engineering, 15(1): 41-47. https://doi.org/10.1061/(ASCE)0899. 1561(2003)15:1(41)

[8] Thangavel, K., Rengaswamy, N.S., Balakrishnan, K. (1995). Influence of protective coating on steel-concrete bond. Indian concrete journal, 69: 289-289.

[9] Haji, S.M. (2008). Performance evaluation of protective coating on steel rebar. Journal of Structural Engineering. 35(2): 137-146. http://hdl.handle.net/10603/29408

[10] Phares, B.M., Fanous, F.S., Wipf, T.J., Lee, Y.S., Jolley, M.J. (2006). Evaluation of Corrosion Resistance of Different Steel Reinforcement Types (No. CTRE Project 02-103). http://www.ctre.iastate.edu/reports/corrosion_resistant_s teel.pdf

[11] ASTM Standard G109. (1999). Standard test method for determining the effects of chemical admixtures on the corrosion of embedded steel reinforcement in concrete exposed to chloride environments. Annual Book of ASTM Standards. 04. 02. ASTM G109-99, 452-455.

[12] Lee, M.G., Hsieh, C.A., Huang, C.C., Yang, T.J. (2009). Corrosion performance of electroless nickel-plated steel. In the Nineteenth International Offshore and Polar Engineering Conference. International Society of Offshore and Polar Engineers.

[13] IS 13620. (1993). Fusion Bonded Epoxy Coated Reinforcing Bars - Specification. 1-2.

[14] ASTM A775/A775M-19. (2019). Standard Specification for Epoxy-Coated Steel Reinforcing Bars. ASTM 
International, West Conshohocken, PA, www.astm.org. https://doi.org/10.1520/A0775_A0775M-19

[15] American Society for Testing and Materials. (1999). Standard test method for half-cell potentials of uncoated reinforcing steel in concrete. ASTM C 876. Annual book of ASTM Standards.

[16] Mainier, F.B., Fonseca, M.P.C., Tavares, S.S., Pardal, J.M. (2013). Quality of electroless Ni-P (nickelphosphorus) coatings applied in oil production equipment with salinity. Journal of Materials Science and Chemical Engineering, 1(6): 1-8. https://doi.org/10.4236/msce.2013.16001

[17] Loganathan, M., Dinesh, S., Vijayan, V., Karuppusamy, T., Rajkumar, S. (2020). Investigation of Mechanical Behaviour on Composites of Al6063 Alloy with Silicon, Graphite and Fly Ash. Journal of New Materials for Electrochemical Systems, 23(1): 36-39. https://doi.org/10.14447/jnmes.v23i1.a07

[18] Loganathan, M., Dinesh, S., Vijayan, V., Ranjithkumar, M., Rajkumar, S. (2020). Experimental Investigation of Tensile Strength of Fiber Reinforced Polyester by Using Chicken Feather Fiber. Journal of New Materials for Electrochemical Systems, 23(1): 40-44. https://doi.org/10.14447/jnmes.v23i1.a08

[19] Dinesh, S., Parameswaran, P., Vijayan, V., Thanikaikarasan, S., Rajaguru, K. (2019). Study on Microstructure and Properties of Al-Cu-Li Alloys for Electrochemical Applications Study on Microstructure and Properties of Al-Cu-Li Alloys for Electrochemical Applications. Journal of New Materials for Electrochemical Systems, 22(1): 11-14. https://doi.org/10.14447/jnmes.v22i1.a03

[20] Saravanan, C., Dinesh, S., Sakthivel, P., Vijayan, V., Kumar, B.S. (2020). Assessment of mechanical properties of Silicon Carbide and Graphene reinforced aluminium composite. Materials Today: Proceedings, 21: 744-747. https://doi.org/10.1016/j.matpr.2019.06.751

[21] Parameswaran, P., Antony, A.G., Dinesh, S., Radhakrishnan, K. (2018). Experimental study on mechanical and corrosion characteristics of nab alloy with the addition of chromium. Materials Today: Proceedings, 5(2): 8089-8094. https://doi.org/10.1016/j.matpr.2017.11.495

[22] Navaneetha Krishnan, G., Selvam, V., Saravanan, C. (2015). Effect of CNTs-Fe2O3 hybrids on mechanical studies of glass fibre/epoxy nanocomposites. Journal of Chemical and Pharmaceutical Sciences, 6: 196-201.

[23] Saravanan, C., Subramanian, K., Anandakrishnan, V., Sathish, S. (2018). Tribological behavior of AA7075-TiC composites by powder metallurgy. Industrial Lubrication and Tribology, 70(6): 1066-1071. https://doi.org/10.1108/ILT-10-2017-0312

[24] Sathish, T., Saravanan, S., Vijayan, V. (2019). Effect of reinforced aluminium alloy LM30 with pure ceramic particles to evaluate hardness and wear properties. Materials Research Innovations, 24(3): 129-132. https://doi.org/10.1080/14328917.2019.1614321

[25] Parameswaran, P., Rameshbabu, A.M., Krishnan, G.N., Yogeshwaran, R., Ramkumar, R. (2018). Study of the corrosion properties in a hot forged $\mathrm{Cu}-\mathrm{Al}-\mathrm{Ni}$ alloy with added Cr. Journal of the Mechanical Behavior of Materials, 20180016. https://doi.org/10.1515/jmbm-2018-0016

[26] Sathish, T., Chandramohan, D., Vijayan, V., Sebastian, P.J. (2019). Investigation on microstructural and mechanical properties of $\mathrm{Cu}$ reinforced with Sic composites prepared by microwave sintering process. Journal of New Materials for Electrochemical Systems, 22(1): 5-9. https://doi.org/10.14447/jnmes.v22i1.a02

[27] Parameswaran, P., Vijayan, V., Radhakrishnan, K., Antony, A.G. (2019). Evaluation of Mechanical Properties of Banana and Glass-Epoxy Hybrid Composites with Addition of Copper Powder. International Journal of Vehicle Structures \& Systems (IJVSS), 11(3): 320-324. https://doi.org/10.4273/ijvss.11.3.20

[28] Dinesh, S., Vijayan, V., Thanikaikarasan, S., Sebastian, P.J. (2019). Productivity and Quality enhancement in Powder Mixed Electrical Discharge Machining for OHNS die steel by utilization of ANN and RSM modeling. Journal of New Materials for Electrochemical $\begin{array}{lll}\text { Systems, } & \text { 22(1): 33-43. }\end{array}$ https://doi.org/10.14447/jnmes.v22i1.a07

[29] Saravanan, S., Balan, A.V., Dinesh, S., Vijayan, V. (2020). Electrochemical machining behaviour of AA6063-TiC composites by using response surface methodology. Materials Today Proceeding, 21(1): 592594. https://doi.org/10.1016/j.matpr.2019.06.721 